\title{
Experimental Studies of a Passive Cooling Roof in Hot Arid Areas
}

\author{
Hamida Ben Cheikh ${ }^{*}, 1$ and Ammar Bouchair ${ }^{2}$ \\ ${ }^{I}$ Département d'architecture, Universite' de Laghouat, Laghouat, Algeria \\ ${ }^{2}$ Laboratoire de Recherche Cadre Bâti et Environnement (LRBCE), Département d'Architecture, Faculté' des Sciences \\ de I'Ingénieur, Université' de Jijel, Jijel, Algeria
}

\begin{abstract}
An experimental study of passive cooling roof was carried out for a typical summer day of June for Laghouat in Algeria. The proposed roof design is composed of a metal plate ceiling over which lies a bed of rocks in a water pool. Over this bed is an air gap separated from the external environment by an aluminium plate. The upper surface of this plate is painted with a white titanium-based pigment to increase the radiation reflection process during daytime. Several passive modifications have been introduced to the roof in order to reduce indoor air temperature in hot climates. An experimental investigation, employing passive procedure, has been carried out to study the possibility of reducing air temperature in buildings. The results show that the air temperature can decrease with a range from 6 to $10^{\circ} \mathrm{K}$. This decrease can further be lowered by 2 to $3^{\circ} \mathrm{C}$ if night natural ventilation of buildings is allowed.
\end{abstract}

Keywords: Evaporative cooling, evapo-reflective, roof, hot dry climate, night ventilation.

\section{INTRODUCTION}

In regions with arid climates such as Laghouat in southern Algeria, excessive heat is the major problem that causes human thermal discomfort [1]. Colling is then is the basic requirement of building occupants. In modern buildings, this can be provided by mechanical and electrical instruments. Traditional architecture in hot climate had many passive aspects which contributed to thermal comfort in dwellings, ie, compact urban heavy building structure, white painted external surfaces, blind facades, open courtyards, etc. The presence of trees, vegetation and water around the building in modifying the thermal microclimate was well appreciated. With the advent of energy crisis there has been a renewed interest in those aspects of architecture which contributed to thermal comfort in a building without or with minimum energy consumption [2-4]. Unlike rural areas, where the building is most exposed to external environment via its facades and roof, in urban area the most exposed part of the building to radiation and winds is the roof as shown in Fig. (1). In many studies [1,5-7] the heat gain through the roof present $50 \%$ of the total heat gain in buildings.

In recent years, several investigations were performed and showed that there can be multiple solutions to the excessive heat problem through the roof $[3,8,10]$. The use of low emissivity material in the attic of a building reduced the underside ceiling surface temperature, which lowered the room air temperature [8]. The evaporative cooling approach for passive cooling of buildings in hot arid climates has also become an attractive subject of investigation for many researchers. The relative advantages of evaporative cooling in relation to many other approaches (cavity wall, insulation, whitewash and large exposure orientations, vegetable pergola shading, roof with removable canvas, water film, soil

\footnotetext{
*Address correspondence to this author at the Département d'architecture, Universite' de Laghouat, Laghouat, Algeria ; Tel: +213 (0) 63369396; Email: h.bencheikh@mail.lagh-univ.dz
}

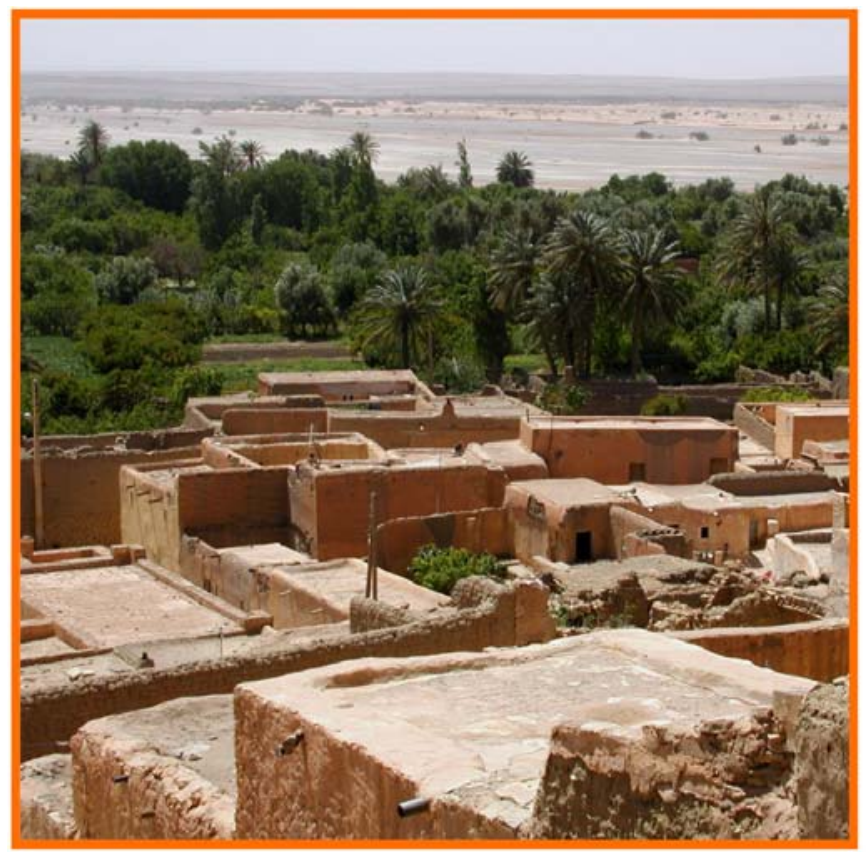

Fig. (1). Roofs exposed to solar radiations.

humid grass and roof with white pots as cover) were demonstrated in $[9,10]$. The reduction of heat gain through the roofs using evaporative cooling systems was extensively investigated with open roof ponds [11, 12], on water spraying over the roof, moving water layer over the roof, thin water film and roofs with wetted gunny bags [13, 14]. Chandra and Chandra [13] have developed a periodic heat transfer model to study the effects of evaporative cooling using water spray and variable ventilation on the temperature control of a non-air-conditioned building. All these passive cooling systems sited requires a considerable amount of water, which is scarce in hot arid areas, and the average day night temperature was not taken into account to improve these passives cooling systems. 
The present study suggests an improved roof design by combining the advantages of the previously described cooling techniques (water ponds, low emissivity surfaces) and inserted rocks of high thermal capacity. The resulting design can be more advantageous and effective than other systems for reducing heat during daytime and storing coolness at night. High thermal capacity materials (rock bed) will delay the entry of daytime heat into the building by such a period that it reaches the interior during the evening, when it is least bothersome and often welcome. The roof is composed of steel plate ceiling and a flat aluminium plate separated by an air space partially filled with high thermal capacity rocks placed in a small quantity of water. The system is properly closed to prevent water vapour escaping outside. A schematic diagram of the model design is shown in Fig. (2).

The choice of the roof for our investigation comes from the fact that $50 \%$ heat load passes through it. The reduction of heat transmission via the roof was investigated for a typical summer day of June for Laghouat in Algeria (Latitude $33.43^{\circ} \mathrm{N}$, Longitude $2.56 \mathrm{E}$ ). Theoretical results shows that the most significant factors affecting the cooling power of the passive cooling roof were the rocks, water volume, aluminium roof thickness and roof air space width [1]. The rocks water volume was 6.5 litres. The weight of the rocks was $65 \mathrm{~kg}$. The width of the air gap was variable from $17 \mathrm{~cm}$ to $27 \mathrm{~cm}$.

\section{EXPERIMENTAL MEASUREMENTS}

Field measurements were conducted at Laghouat University. The experimental set-up consisted of two identical test cells (A) and (B) fabricated of steel structure, each having dimensions $(0.70 \times 0.7 \times 0.90) \mathrm{m}^{3}$. Fig. (3) shows the con- figuration of tested cells. The experimental cell (A), is made of metal frame of $(0.70 \times 0.7 \times 0.90 \mathrm{~m})$ interior edge, all sides were strongly insulated by $4 \mathrm{~cm}$ thick polystyrene except the roof. The cell was elevated by $50 \mathrm{~cm}$ above the ground using four metal supports as shown in Fig. (3). In the North wall a steel door of $30 \mathrm{~cm}$ x $60 \mathrm{~cm}$ dimensions upon which a $4 \mathrm{~cm}$ thick extruded polystyrene foam panel was fixed. In the south wall a window of $35 \mathrm{~cm}$ x $37 \mathrm{~cm}$ dimensions, plastic netting, of fine meshes was fixed on the window exterior face, to limits the transmission of the solar radiation (Fig. 3). The door and the window are used two allow night natural ventilation. The experimental cell (B) was the basic reference unit. The roof was constructed of simple aluminium sheet painted white (Fig. 4).

\section{TEMPERATURE MEASUREMENTS}

Air temperatures outside the room were measured using a metheological station installed near the laboratory, far from the test cell by $150 \mathrm{~m}$. The temperature at different positions under the roof level has been measured by copper constant thermocouples connected to digital thermometer. Thermocouples fixed under the roof surface the end of the thermocouples were enveloped in thin aluminium paper to reflect the radiation from the surrounding interior surfaces.

The readings of all thermocouples have been averaged to give the average temperature.

\section{RESULTS AND DISCUSSION}

Hourly variations of the inside air temperature for typical summer day by using evaporative reflective roof measured and presented in Fig. (5). for different values of air gap width $(17,22$ and $27 \mathrm{~cm})$. The ambient air temperature is also given

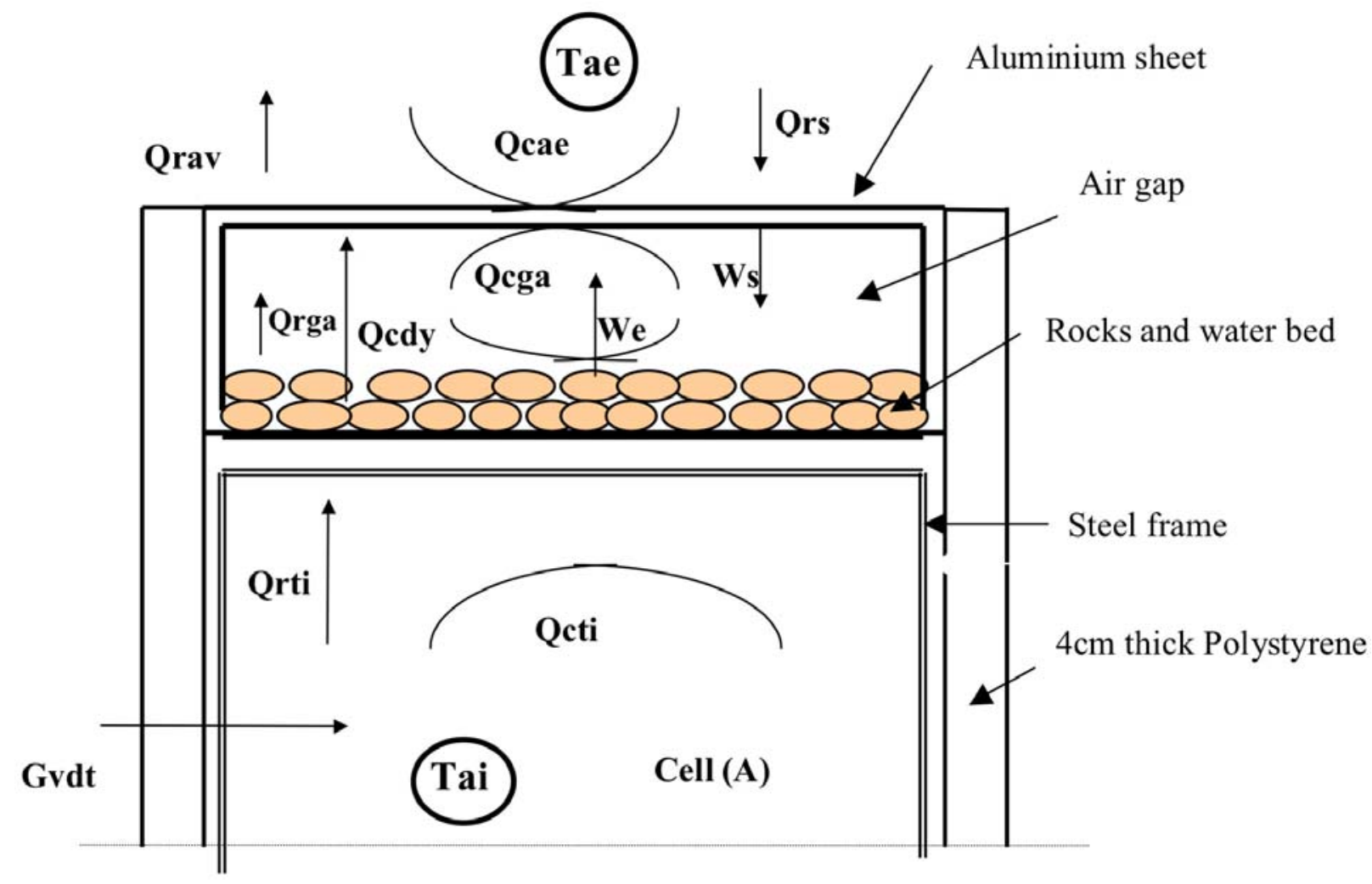

Fig. (2). A schematic diagram of the model design. 


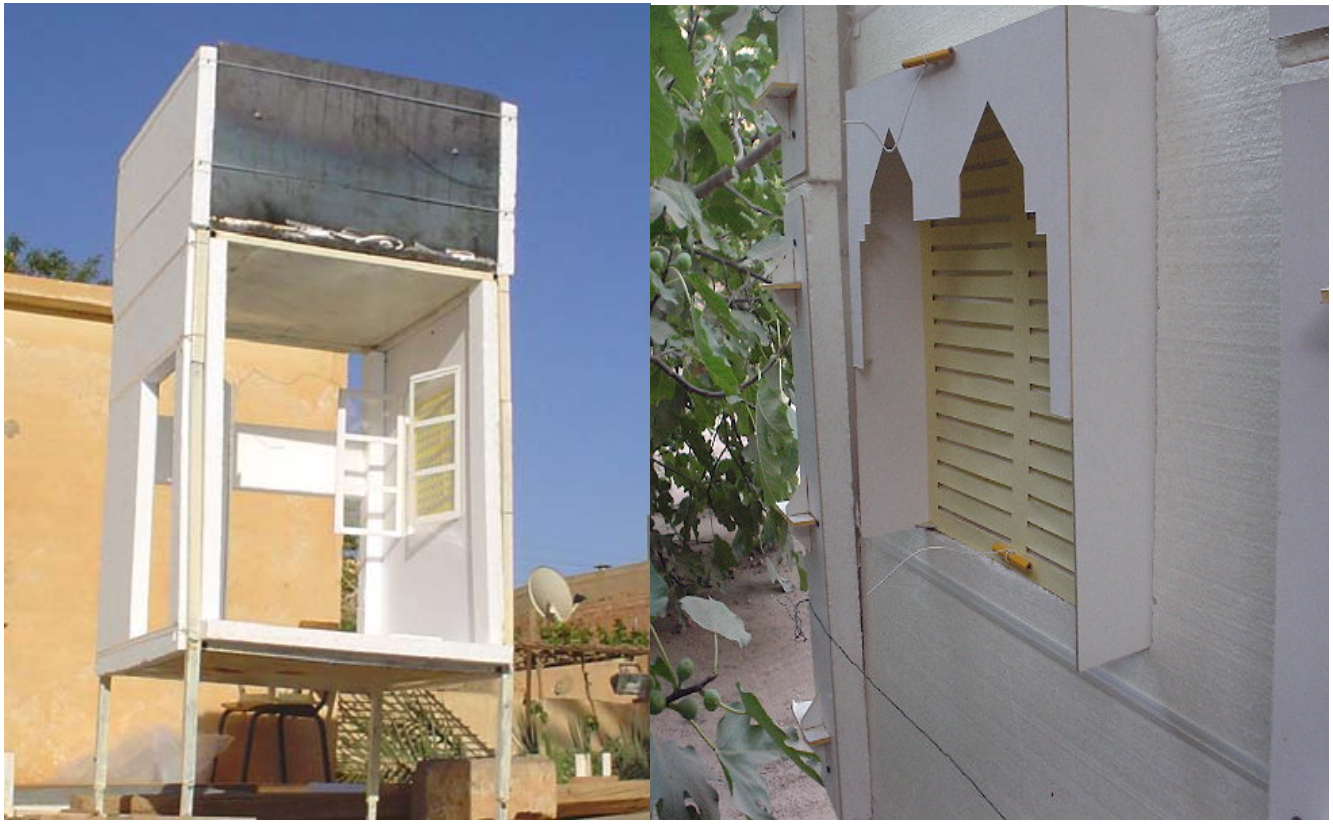

Fig. (3). The experimental cell.

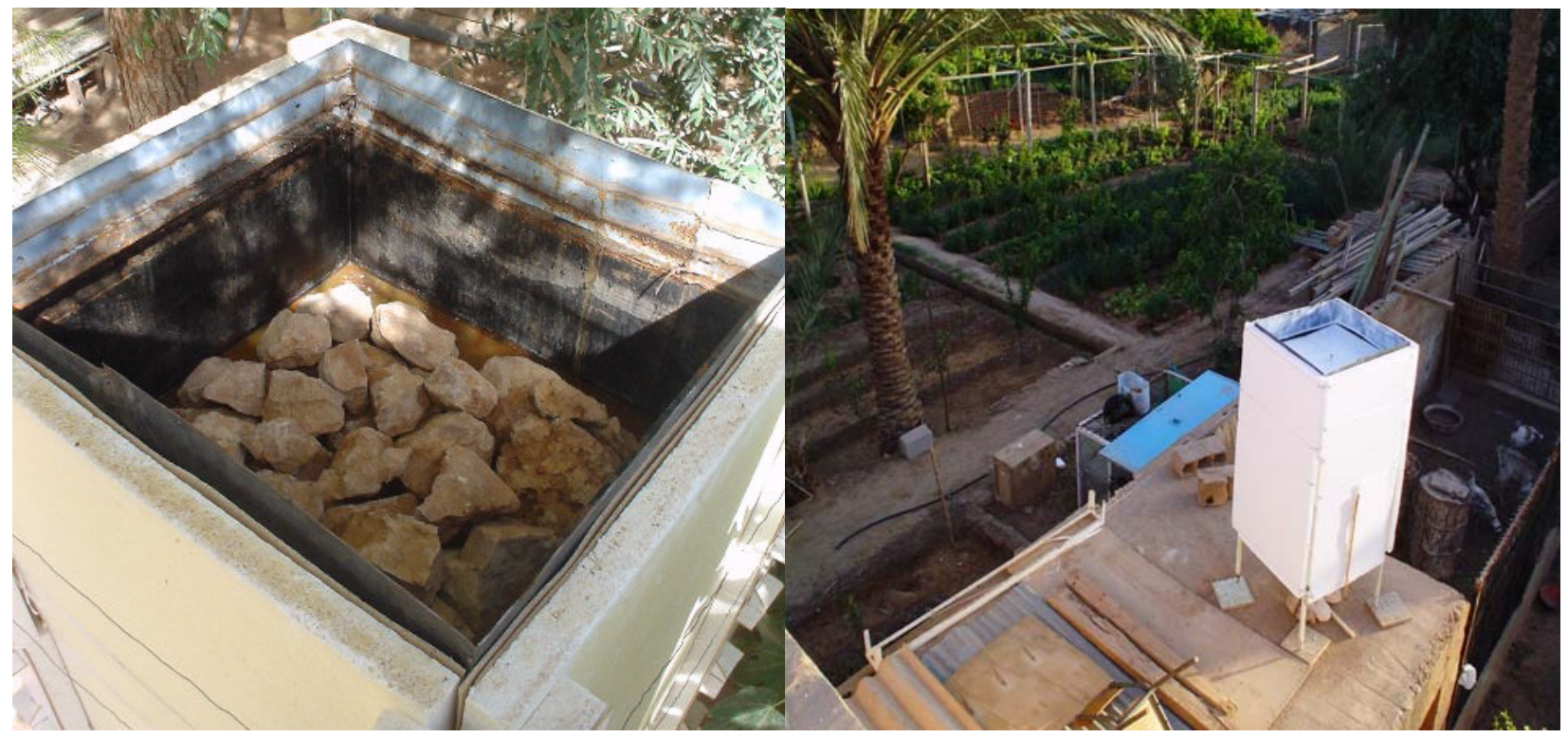

Fig. (4). The evapo-refletive roof.

in these figures to observe the effective cooling. Roof without any treatment gives the maximum inside air temperature $\left(48^{\circ} \mathrm{C}\right)$ when the ambient air temperature was $38.5^{\circ} \mathrm{C}$ during day hours. However during night hours the inside air temperature fall down to the ambient air temperature. Roof with evaporative reflective roof, when the air gap width fixed at $17 \mathrm{~cm}$ gives higher inside air temperature $\left(42,5^{\circ} \mathrm{C}\right)$ than $22 \mathrm{~cm}$ air gap by two degree $\left(40,5^{\circ} \mathrm{C}\right), 27 \mathrm{~cm}$ air gap in the roof gives the same inside air temperature as the $22 \mathrm{~cm}$ air gap, that means the optimum air gap is $22 \mathrm{~cm}$.

Fig. (6) shows a comparison of room air temperatures with cooling roof system and with bare roof without room night natural ventilation. It can be seen from this figure that the evaporative reflective roof can reduce the internal room air temperatures during the day up to $10{ }^{\circ} \mathrm{C}$ in comparison to the air temperatures for a bare roof over the room (Fig. 7). is the comparison of room air temperatures with cooling roof system and with bare roof when room night natural ventilation is allowed. The ventilation was allowed from 8 pm till 9 am, a period when the outside air temperature is relatively low. This can significantly improve cooling of room air temperatures, as shown in Fig. (8).

\section{CONCLUSION}

The air temperature inside the test cell treated with evapo-reflective roof has been studied around the clock for variable air gap inside the roof system, in the summer of 2004. The inside air temperature can be reduced by 6 to $10^{\circ} \mathrm{C}$, with an optimum of $22 \mathrm{~cm}$ air gap, then the performance of the roof with cooling system was improved when night natural ventilation was allowed through the test cell opened window and door during night time, which decrease the inside air temperature by 2 to $3^{\circ} \mathrm{C}$. 

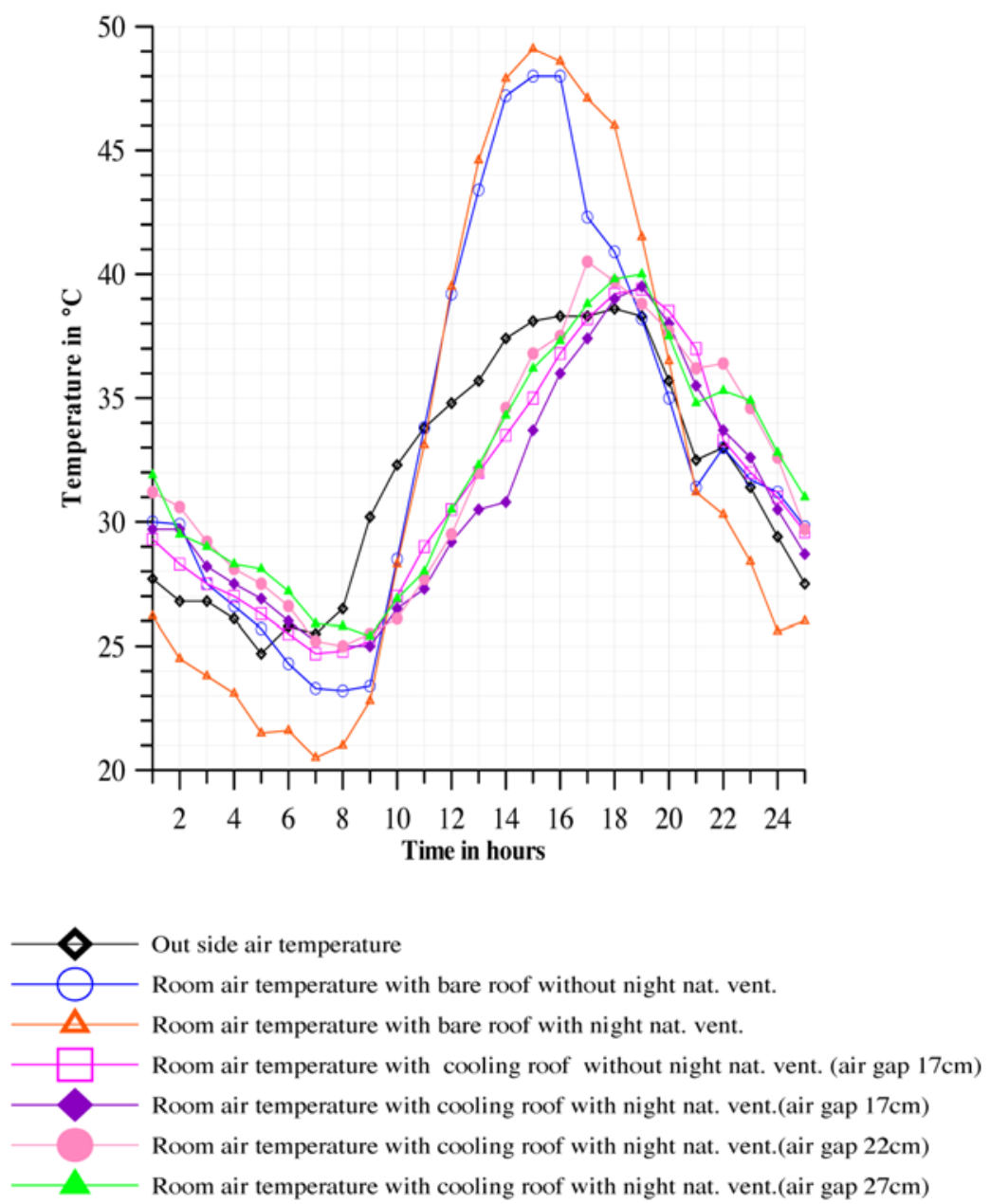

Fig. (5). Comparison of measured room air temperature when roof system is functioning and when the roof is bare (for ventilated and non ventilated cases for variable air gap dimensions).

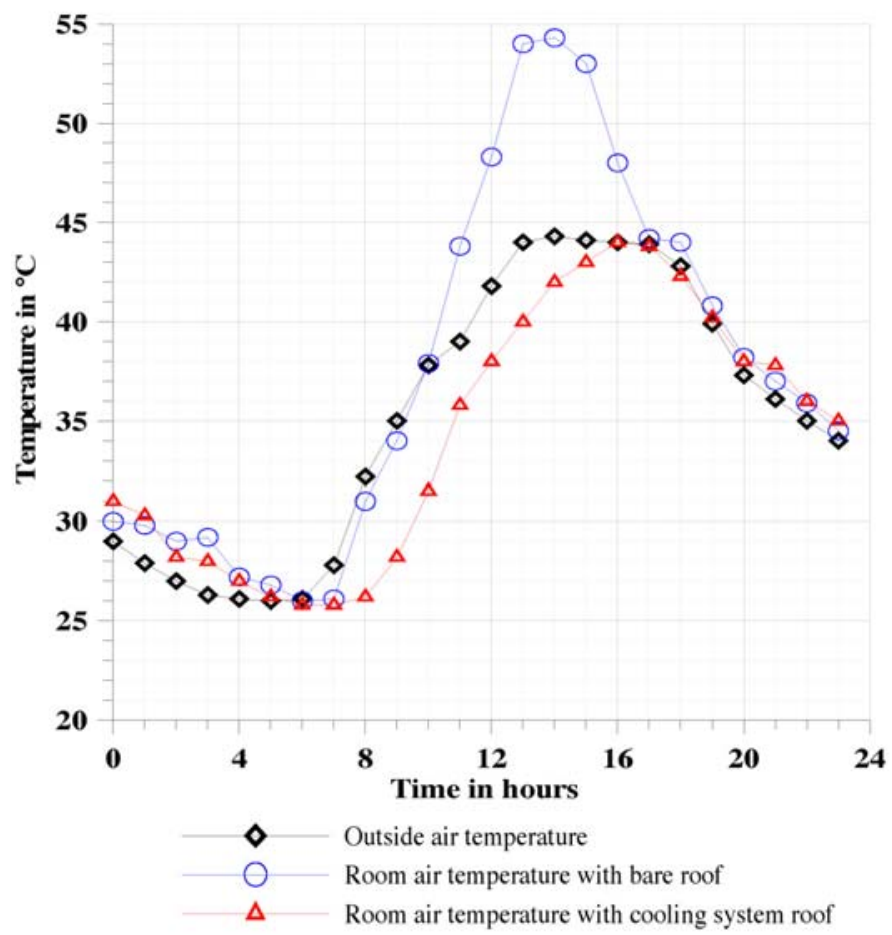

Fig. (6). Comparison of room air temperature when roof system is functioning and with bare roof (without ventilate). 


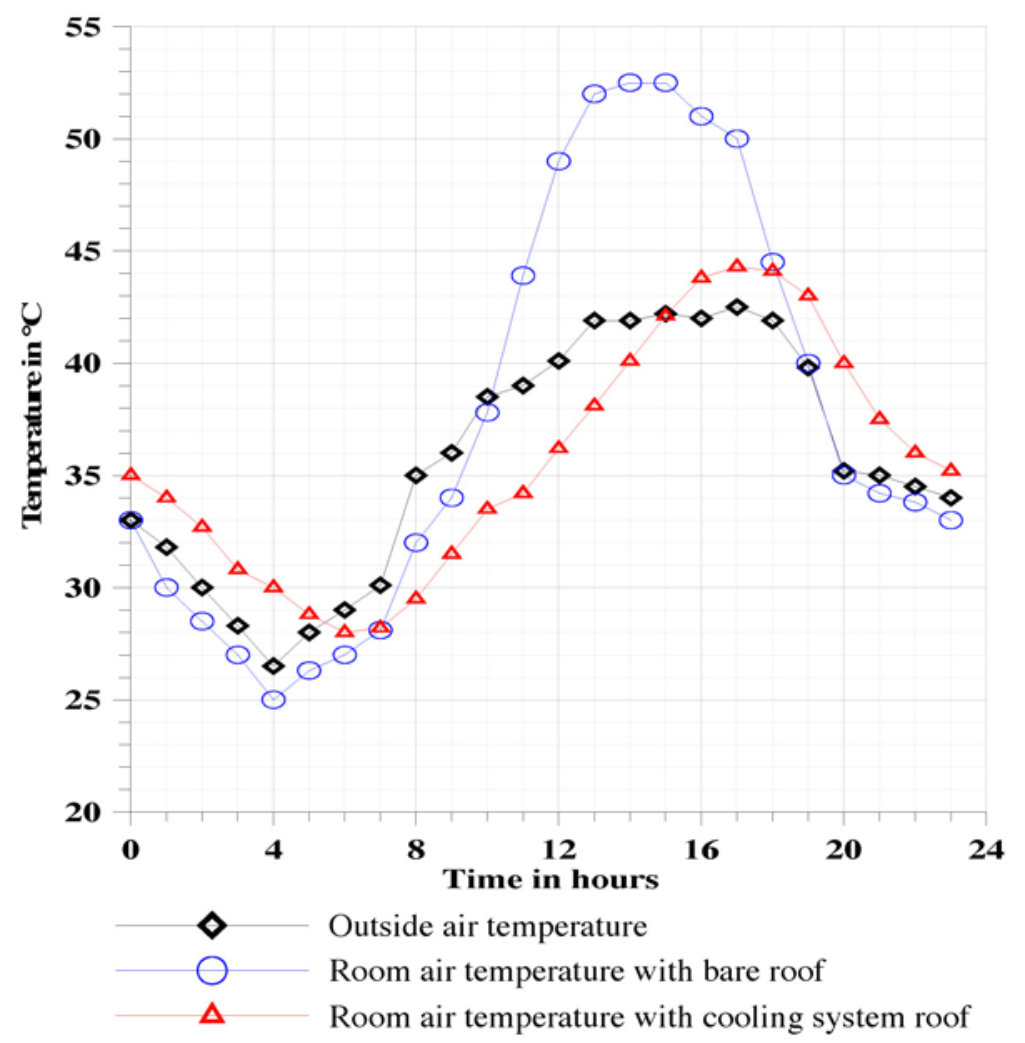

Fig. (7). Comparison of room air temperature when roof system is functioning and with bare roof (with ventilate).

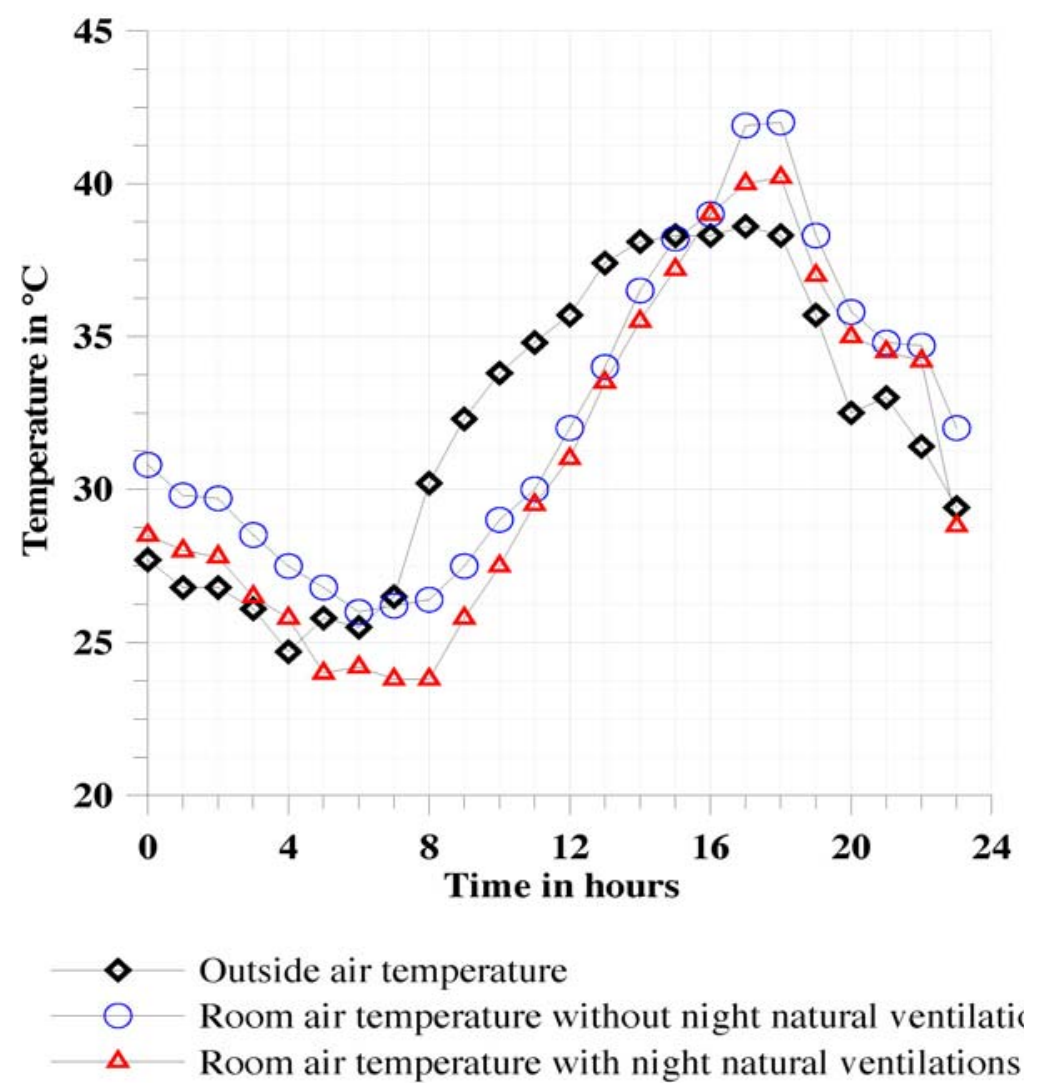

Fig. (8). Comparison of room air temperature when roof system is functioning for ventilated and non ventilated cases. 


\section{ABBREVIATIONS}

Tae $=$ Outside air temperature $\left({ }^{\circ} \mathrm{C}\right)$

Tai $=$ Inside air temperature $\left({ }^{\circ} \mathrm{C}\right)$

Qrav = Heat change by radiations between the roof and the sky (w)

Qcae = Heat change by convections between the roof and the outside air temperature Tae (w)

Qrs = Heat gain from solar radiations $(\mathrm{w})$

Ws = Heat change by condensation ( $\mathrm{w}$ )

$\mathrm{We}=$ Heat change by evaporation $(\mathrm{w})$

Qrga = Heat change by radiations between the roof and rocks water upper surface (w)

Qcdy = Heat change by conduction between rocks (w)

Qcga = Heat change by convection between the air and rocks water upper surface $(\mathrm{w})$

Qrti = Heat change by radiations between the inside wall surfaces and the roof inside surface $(w)$

Qcti = Heat change by convection between the inside air and the roof inside surface (w)
Gvdt $=$ Heat change between Tai and Tae, through exterior walls and by natural ventilation (w)

\section{REFERENCES}

[1] Ben Cheikh, H.; Bouchair, A. Renewable Energy, 2003, 29, 1886.

[2] Bouchair, A. Solar induced ventilation in the Algerian and similar climates. PhD thesis. UK: University of Leeds; 1989.

[3] Bouchair, A. Building and environment, 2004, 36, 732.

[4] Bouchair, A.; Dupagne, A. Building and Environment, 2003, 38, 1364.

[5] Runsheng, T.; Etzion, Y.; Erell, E. Building and Environment, 2003, 28, 1522 .

[6] Jain, D. Building and Environment, 2006, 41, 287.

[7] Amer, E. H. Energy, 2006, 31, 1344

[8] Nahar, NM.; Sharma, P.; Purohit, MM. Building and Environment, 2003, 38, 116.

[9] Lambert, R. Heat transfer through roofs of low cost Brazilian houses. PhD thesis. UK: University of Leeds; 1988.

[10] Verma, R.; Bansal, NK.; Garg, HP. Building and Environment, 1986, 21, 69 .

[11] Nayak, JK.; Srivastava, A.; Singh, U.; Sodha, MS. Building and Environment, 1982, 17, 161.

[12] Sodha, MS.; Singh, U.; Tiwari, GN. Applied Energy, 1980, 7, 307.

[13] Chandra, S.; Chandra, S. Solar energy, 1983, 30, 387.

[14] Sodha, MS.; Srivastava, A.; Kumar, A.; Tiwari, GN. Applied Energy, 1980, 7, 229. 